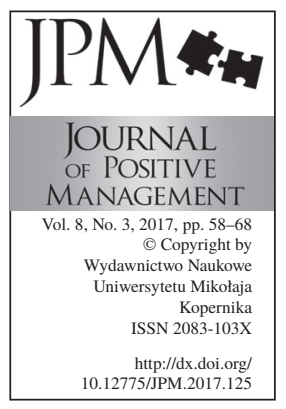

\title{
CUSTOMER VALUE DEVELOPMENT IN THE LIGHT OF DESIGN THINKING APPROACH
}

\author{
Anna Dziadkiewicz
}

University of Gdansk

Faculty of Management, Gdansk, Poland

e-mail: anna.dziadkiewicz@ug.edu.pl

\begin{abstract}
Purpose: The aim of this study is to ascertain the meaning and characteristics of the entrepreneurs' empathy as the most significant approach for modern business and its role in design thinking methodology, where empathy is used for multiple purposes.

Methodology: Literature review on design thinking approach and objectives, empathy and customer value development as well as abstract modelling and synthesis is the methodology of this study.

Findings: Content analysis shows that among the many approaches and definitions of the entrepreneurs' empathy to the customers, none directly points the role of design thinking in ensuring customer value development. There has been a conceptual transition to integrated conceptualization of design thinking, which allows the theoretical assumptions to move beyond traditional design practices and theories, and there is a potential for new design approaches focused on customer experience that promote customer and business value.

Originality/value: The novelty of this study is a presentation of meaning and characteristics of the entrepreneurs' empathy, its role in design thinking approach, as well as development models which both refer to the value for customers and business. The author proposes a new approach and conceptual framework for design thinking process in order to promote solutions which allow to build a new customer value by entrepreneurs.
\end{abstract}

Keywords: design thinking, customer value development, empathy, customer experience design, value proposition canvas, business model canvas

Paper type: Conceptual Paper

\section{Introduction}

For last few decades we have been facing a significant and unlimited demand for products and services. The selection of offers and its variety, the number of communication channels and other management tools encourage customers to purchase products and services and make the potential customer confused. Product life cycles are getting shorter, companies have changed their structures to be more effective, products that were sold only in one country, have become 
immediately available abroad, there is no purchase and sales barriers. Therefore business decisions have been mainly made as a result of detailed calculations. But the customer has been still unpredictable, which means it is impossible to describe him in an obvious way.

It is worth noticing, a regular observation can be only descriptive, and it does not include with essential point for entrepreneurs - a detailed observation of customers behaviour incentives, which empathy - the first step of design thinking process - is responsible for. If the Nobel Prize winner professor Daniel Kahneman's statement about the advantage of memories over experience and 90\% emotional-based human decisions is true (Kahneman, 2003), there is a real need to notice a process of customer value development not only from theoretical point of view, but as practical management concept in particular, which is one of the main aims of the article.

\section{Design thinking approach}

Marketing is commonly called the experience economy. The latter term was first described in an article published in 1998 by B. Joseph Pine II and James H. Gilmore, entitled "The Experience Economy". They described the experience economy as the next economy following the agrarian economy, the industrial economy, and the most recent service economy. Pine and Gilmore argue that businesses must orchestrate memorable events for their customers, and that memory itself becomes the product - the "experience". More advanced experience businesses can begin charging for the value of the "transformation" that an experience offers, e.g., as education offerings might do if they were able to participate in the value that is created by the educated individual (Lonsway, 2009). This, they argue, is a natural progression in the value added by the business over and above its inputs (Pine and Gilmore, 1999). The experience economy is also considered to be the main underpinning for customer experience management. As a result, marketing has exploded in many ideas and concepts such as emotional branding, customer insights, crowdsourcing, lovemarks, 3D marketing, customer value marketing, gamification, neuromarketing, SEO, etnographic research, sensory branding, lateral marketing and design thinking.

In the last few years, design thinking approach has been considered as one of the most effective ways to develop a creativity and innovation in a team and/ or organisation. It helps to solve complex problems, also those without logical foundation (Buchanan, 1992) and to innovate product and service. In some researchers' opinion, the future of design thinking is uncertain, but from the management research field we can observe that traditional management methods are not as effective today as a few decades ago and some of the previously strongest supporters are confident the era is over. It is due to running the business in a turbulent market and changing customers' behaviour. 
CUSTOMER VALUE DEVELOPMENT IN THE LIGHT

Anna Dziadkiewicz

Figure 1. Overview of design thinking Source: Gasparini, 2015 .
There are many reasons why design thinking is chosen. Two fields, business management and design research, are considered to be pulling design thinking in two very different directions.

On the one hand, company management has adapted design thinking to its conditions as Nussbaum wrote (Nussbaum, 2011) "Companies absorbed the process of design thinking all too well, turning it into a linear, gated, by - the book methodology that delivered, at best, incremental change and innovation". On the other hand, design research has developed a different approach. In that case thinking as a designer is not a new remedy against business issues and possibly therefore the concept has been overlooked. Its strength is an ability to combine experience, the economic viability and the technical feasibility of an innovative idea (see figure 1).

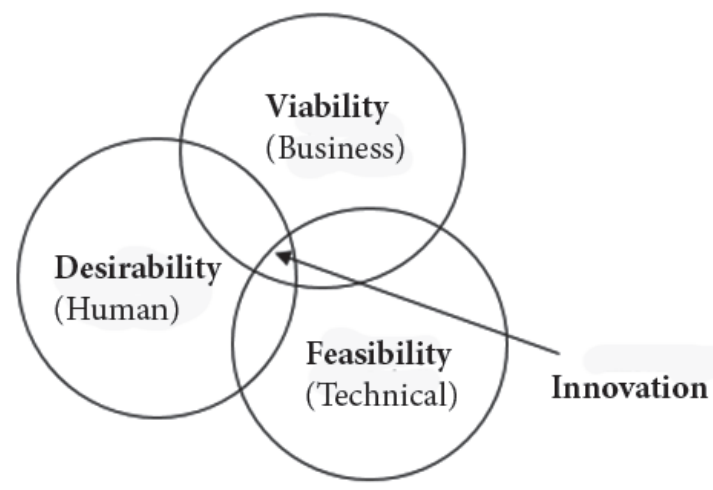

Design thinking may help to launch products and service innovation fast and effectively. According to Brown and Wyatt (Brown, 2009; Brown and Wyatt, 2010), the approach to use the connected elements such as detailed understanding of customers' needs, rapid prototyping, that provokes small progresses, based on partially known information (Collins, 2013), and reasoning, can bring the most effective outcome.

Although entrepreneurs emphasise on all three elements - rapid prototyping, reasoning and empathy to implement innovative solutions, the focus of this article will be on the latter as the most important for both customer and business value development.

\section{Empathy as a starting point for business}

Empathy assures a broad representation of knowledge in the process (Gasparini, 2014) while reasoning explains why the result is adequate, given the context. The process of design thinking according to its founder Tim Brown (2014) lets the result to be a technical viable outcome, a desirable output for users and/or customers and an economical feasible project (see Figure 1). Another strength 
is an ability to face complex, badly-defined processes (Brown and Wyatt, 2010), covering business in a social context (Stolterman, 2008).

Bearing in mind the emphasis on outcomes, two approaches of empathy are possible - emotional aspect that is instinctual, effective, accessible and mirrored experience (Spencer, 1881) which means that one can feel what other people feel, and cognitive aspect, when one understands how people can experience the world in their point of view (Spencer; 1881, New and Kimbell, 2013). In design process, empathy can be used for multiple purposes. Firstly, a tool to design and transform emotional feelings (Koskinen et al., 2003). Secondly, designers can use empathy as a set of features to gain insight into users' needs and in doing so, create the design process (Brown, 2009). It is worth mentioning, in a design thinking process, all design team members need to be empathetic for users they are designing for, in order to create relevant solutions. Using cognitive empathy, designers apply different methods to develop competence and insight, enabling them to prioritize the needs of users, and making the results of the process more desirable (Brown, 2009).

\section{Cognitive empathic insight - a selection of approaches}

Designers may use a variety of approaches to gain a cognitive insight into users' and/or customers' needs. Traditional marketing views them as rational decisionmakers who care about feasibility and benefits, based on well-balanced analysis of both enrichment and financial loss. In contrast, design thinkers view customers as emotional people who are focused on achieving pleasurable experiences. So this has become a rule that luxurious brands' owners are not afraid of competitors but the customers' awareness and practical wisdom. When purchasing luxurious brands it is not calculations that matters, but emotions.

Another example shows an incredible transformation of marketing role. The traditional marketing has been aimed at customer identification with a brand and/ or a company. Nowadays, the message is different - intrusive marketing activities aimed at quick sale. Jarosław Szeremeta, art director of "Brasil" advertising agency described one whisky promotion campaign launching this product in Polish at the end of XX century. The boss of the company that had ordered this campaign, was a Scotsman, who wanted his customers to be aware of the fact, why they buy his whisky. Szeremeta organised sophisticated marketing activities such as whisky snack counters, workshops for whisky-lovers, distribution of leaflets that smelled like wood, peat and smoky salmon. It was challenging, because it demanded creativity, but the campaign was really successful. A few years later, a Pole was a new boss and he agreed only for one marketing slogan on the whisky bottle - "New whisky, cheap" (Staszewski, 2016). We must not allow ourselves to be misled by fine-sounding, but empty statements relating to the consumers. They are wise and observing the company actions.
CUSTOMER VALUE DEVELOPMENT IN THE LIGHT

Anna Dziadkiewicz 
CUSTOMER VALUE DEVELOPMENT IN THE LIGHT

Anna Dziadkiewicz
Therefore five different types of experiences (modules) that marketers and design thinkers can create for customers are distinguished (Dziewanowska and Kacprzak, 2013): sensory experiences (SENSE); affective experiences (FEEL); creative cognitive experiences (THINK); physical experiences, behaviours and lifestyles (ACT) and social-identity experiences that result from relating to a reference group or culture (RELATE).

All these experiences mentioned above are implemented by so-called experience providers (ExPros), such as social media, visual and verbal identity, new product development (NPD) strategy and communications.

Sensory experience practiced by entrepreneurs is aimed at expressing a corporate identity by design (corporate design is also called a visual identity as a part of corporate identity). Marketing specialists and design thinkers realise that understanding of the reality works through senses, that in turn trigger and boost emotions (Lindstrom, 2005). According to Lindstrom many entrepreneurs decide to replace communication activities with a sense synergy.

Affective experience in marketing (Schmitt, 1999a; Gardner, 1985; Jachnis 2007) varies from negative to strong positive e.g. an anger, satisfaction or pride connected with product or brand purchase.

Creative cognitive experiences are driven by the intellect and logical thinking, thus marketing activities encourage audience to customized, creative thinking about the products and company in general e.g. presenting of annual reports as interesting tools or presenting a boring company history through unusual storytelling.

Physical experiences, behaviours and lifestyles make the customers' life richer and more interesting by discovering alternative lifestyles. It is worth mentioning, that ACT module was ignored by traditional marketing. Although marketing activities attempted to have an influence on customers' decision making process and to predict their lifestyles, but without a deep understanding of physical experiences, behaviours and lifestyles, that is an essence of empathy and other efforts connected with experiential marketing (Schmitt, 1999b).

Social-identity experiences go beyond individual feelings, physical experience and individual activities and place the customer in a broader social-cultural context. In relationship module, there are links not only between an individual and the group of people or different social groups but also between an individual and abstract existence such as nation, society and culture. As a result of RELATE activities, the experiences typical for all modules mentioned above emerge, but play a secondary role in a relationship between a customer and a brand in social context. To be more specific, the fundamental is to understand a symbolic meaning that customers give to the products they own. There is also a tendency (e.g. Fournier, 1998) to describe the relation to brands such as relation with other people - many customers love, admire, miss or hate some products. Therefore 
we can find so-called brand communities (Muniz Jr and O'Guinn, 2001), that are interested in the same brand, create subcultures with their own values, rituals, myths, vocabulary and hierarchy (Cova and Pace, 2006).

\section{Customer experience design}

One of the most common design thinking outcome is a construction of customer experience, best understood as a way of direct interaction between a customer and a brand and / or a company. Implementation of marketing activities based on all types of experience requires an understanding of their character, but well-designed customer experience brings a "life-blood" to the brand that exceeds the features of product or service significantly. The approach to customer-experience design is equally important both for business and customers (users).

Alex Osterwalder and Yves Pigneur noticed the lack of a significant factor a value for a customer. They suggested a single diagram called the business model canvas where the value proposition design is situated at the centre as the primary focus area (see Table 1). The customer building blocks (customer segments, channels and relationships) can be found to the right of the value proposition and infrastructure building blocks (resources, activities and partners) to the left.

\begin{tabular}{|c|c|c|c|c|}
\hline \multirow{2}{*}{ Key partners } & $\begin{array}{l}\text { Key } \\
\text { activities }\end{array}$ & \multirow{2}{*}{$\begin{array}{l}\text { Value proposition } \\
\text { What do you provide to customers? } \\
\text { Describe the bundle of products } \\
\text { and/or services that provide value } \\
\text { to customers }\end{array}$} & $\begin{array}{l}\text { Customer } \\
\text { relationships }\end{array}$ & \multirow{2}{*}{$\begin{array}{l}\text { Customer } \\
\text { segments }\end{array}$} \\
\hline & $\begin{array}{l}\text { Key } \\
\text { resources }\end{array}$ & & Channels & \\
\hline Cost structure & & Revenue structure & & \\
\hline
\end{tabular}

Quite simply a business model is a description of the rationale of how an organisation creates, delivers and captures value. It describes how a company creates its offer, and generates profit from the transaction. Summarising, the table presents a clear value for business.

Business model canvas cannot be designed without simultaneous designing of value proposition canvas depicted in Figure 2. This diagram presents relationships development between a brand or company and a customer, where design thinking method is used. In order to make it effective, empathy is crucial.

The main strength of Customer Development model, depicted in Figure 3, is its simplicity. The model separates out all the customer-related activities in the early stage of a company into their own processes, designed as four easy-tounderstand elements based on customer value - discovery, validation, creation and company building, that tends to develop a company value. This model is especially useful for start-ups, unlike NPD strategy (Dziadkiewicz, 2014) common-
CUSTOMER VALUE DEVELOPMENT IN THE LIGHT

Anna Dziadkiewicz
Table 1. Business model canvas value for business Source: Fisher, 2011. 
CUSTOMER VALUE

DEVELOPMENT

IN THE LIGHT

Anna Dziadkiewicz

Figure 2. Value

Proposition Canvas value for customers

Source: Osterwalder et al., 2014.

Figure 3. Customer Development Model Source: Blank, 2009.
PRODUCT

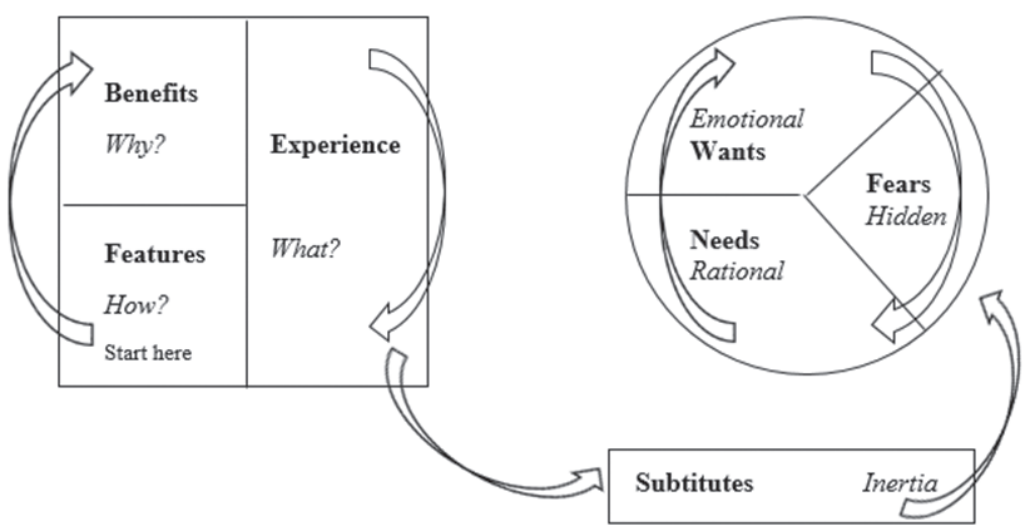

implemented by companies that have already existed. The second major difference between this model and tradition development model is that each step is drawn as a circular trail with recursive arrows. Both circles and arrows highlight the fact that each step, that result in specific deliverables, in customer development is iterative. The customer development model should not replace the NPD model, but be accompanied by it. It focuses on understanding customer problems and needs, followed by validation which focuses on developing a sales model, possible to be copied. Then customer creation which focuses on creating the end-user demand and finally, the last company building which focuses on transforming the company from one designed for learning and discovery to well-functioning organism designed for execution. It must be emphasised that market type choices affect the way the organisation will launch its sales, marketing and financial resources (Blank, 2013).

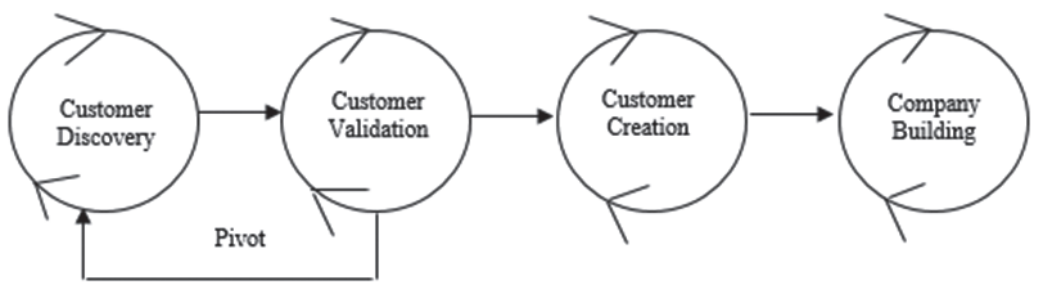

Eric Ries, the author of "lean start up" methodology (see Figure 4) defines a start-up broadly as any "human institution designed to create a new product or service under conditions of extreme uncertainty". According to Harvard 
Business School research, led by Shikhar Ghosh $75 \%$ of all start-ups fail. To make the business less risky, the entrepreneurs can use lean start up that favours experimentation over-elaborate planning, customer feedback over intuition, and iterative design over traditional "big design up front" development. Ries noticed that majority of companies begin with an idea for a product that they think people want. Product development takes months, sometimes years without showing the product (even in a basic form) to potential customer. When they fail to reach broad uptake from customers, it is because they never speak to potential customers. When customers communicate ultimately, through their indifference, they do not care about the idea and the company fails as a result.

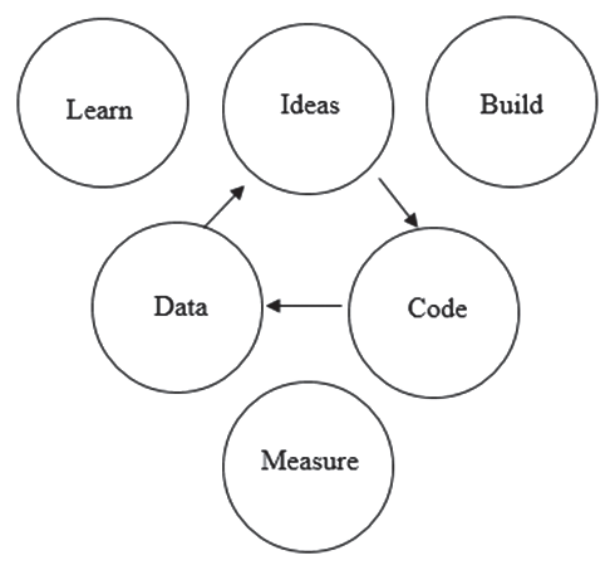

The methodology of lean start-up is a way of doing business that is expanding from start-ups to enterprise businesses, non-profits, and the public sector. Although the knowledge about lean start-up is quite new (about five years), its main idea - minimum viable product and pivoting has been quickly rooted in startup reality and because of its efficiency lots of business schools have adapted their curricula to teach it. The lean start up provides a scientific approach to creating and managing companies and getting a desired product or service to customers' hands faster. It is a principled approach to new product development.

Summarising all approaches mentioned above need to be presented in a value matrix, depicted in Figure 5.

As we can see on Figure 6 two stages are presented: design as a preliminary phase and testing as a phase of implementation. There are also two views proposed - models for business and value proposition for customers. To understand how business is evolving and to get inspiration for designing an innovative new business model, it is worth examining some of the new patterns emerging.

Over the past 20 years a dissemination of separate parts of matrix has been seen, but to gain complex knowledge about the business and its audience all elements should work together to give a competitive edge for any enterprise, no matter how long it has existed on the market.
CUSTOMER VALUE DEVELOPMENT IN THE LIGHT

Anna Dziadkiewicz

Figure 4. Lean Start-up process Source: Ries, 2011. 
CUSTOMER VALUE

DEVELOPMENT

IN THE LIGHT

Anna Dziadkiewicz
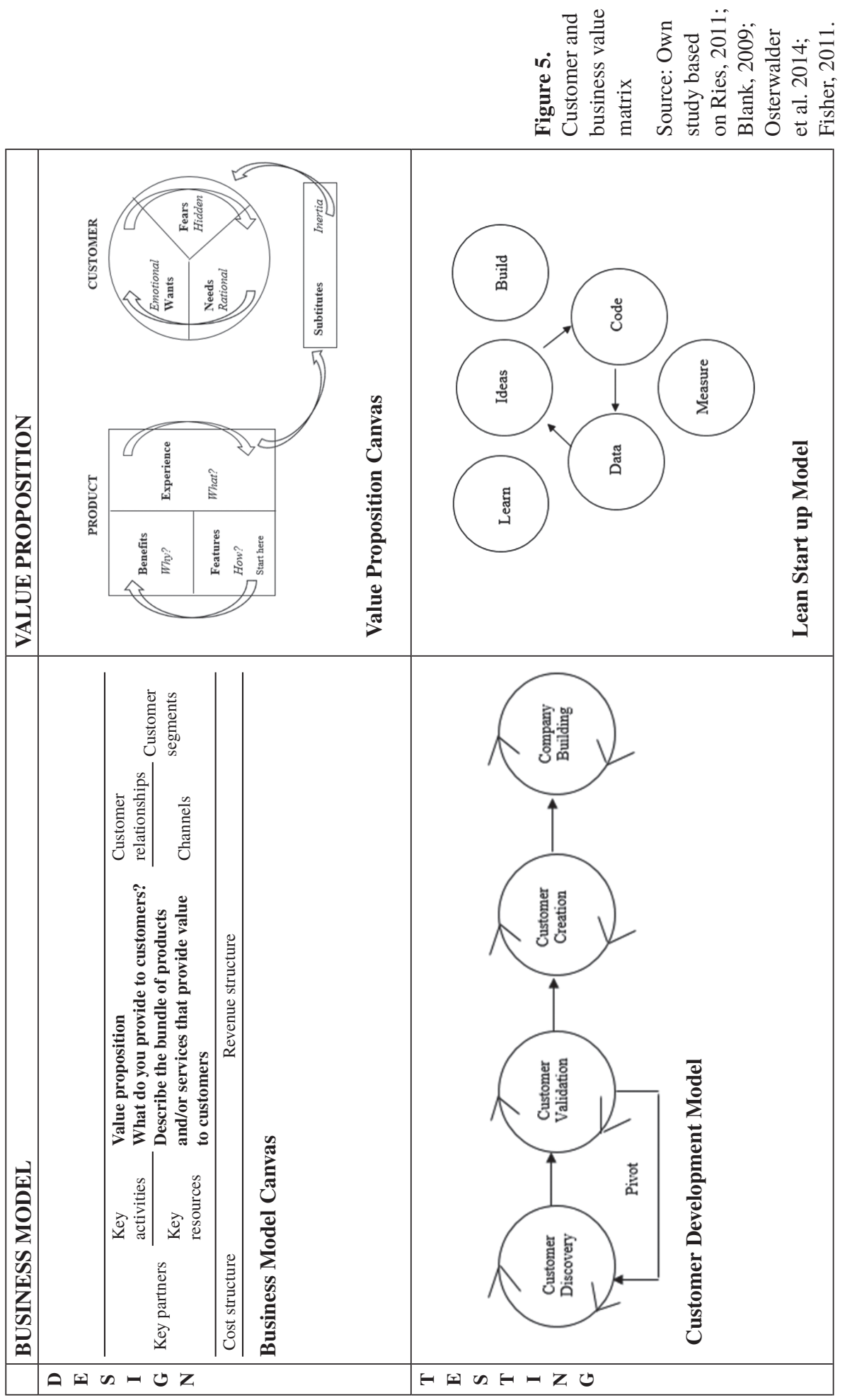


\section{Conclusion}

The end of XX century and the beginning of XXI century made the entrepreneurs aware of the fact that customers are a driving force for more than $90 \%$ of any enterprises. During that time, the marketing role, its range and activities have been evolving and marketing transformation has become a combined effect of many changes that have come round inside and outside of the business. This is also an outcome of specific marketing which focuses on all changes both in business environment and all sectors of life. Evolution process in the world today, as all changes in modern business, are highlighted in design thinking approach in particular as a practical method of running business.

The article was theoretical in nature and provided a general review of the approach of design thinking, where empathy was used for multiple purposes. However, the discussion taken in this article encourages to undertake further research that the Author intend to take in the future. Indicated importance of the entrepreneurs' empathy as the most significant approach for modern business and its role in design thinking methodology, confirm the need for further verification of the proposed applications. The results of further work the Author will present in the following scientific publications.

\section{References}

Blank, S. (2013), The Four Steps to the Epiphany. Successful Strategies for Products that Win, K\&S Ranch, Pennsylvania.

Brown, T. (2009), Change by design: how design thinking transforms organizations and inspires innovation, Harper Business, New York.

Brown, T., Wyatt, Y. (2010), "Design Thinking for Social Innovation (SSIR)", Stanford Social Innovation Review, Vol. 30 No. 5, pp. 29-53.

Buchanan, R. (1992), "Wicked Problems in Design Thinking", Design Issues, Vol. 8 No. 2, pp. $5-21$.

Collins, H. (2013), “Can Design Thinking Still Add Value?”, Design Management Review, Vol. 24 No. 2, pp. 35-39. DOI: 10.1111/drev.10239.

Cova, B., Pace, S. (2006), "Brand Community of Convenience Products: New forms of customer empowerment - the case "my Nutella The Community", European Journal of Marketing, Vol. 40 No. 9/10, pp. 1088-1089.

Dziadkiewicz, A. (2014), „Rola designu w procesie tworzenia nowego produktu”, Marketing i Rynek, Vol. 21 No. 8, pp. 386-394.

Dziewanowska, K., Kacprzak, A. (2013), Marketing doświadczeń, Polskie Wydawnictwo Naukowe, Warszawa.

Fisher, G. (2011), “Radical Business Model Innovation”, Entrepreneur Magazine, available at: http://www.entrepreneurmag.co.za/advice/starting-a-business/business-model/ radical-business-model-innovation/ (accessed 30 December 2016).

Fournier, S. (1998), "Consumers and their Brands: Developing relationship theory in consumer research", Journal of Consumer Research, No. 4, pp. 342-373.
CUSTOMER VALUE DEVELOPMENT IN THE LIGHT

Anna Dziadkiewicz 
CUSTOMER VALUE DEVELOPMENT IN THE LIGHT

Anna Dziadkiewicz
Gardner, M. (1985), "Mood States and Consumer Behaviour: A critical review”, Journal of Consumer Research, Vol. 12, pp. 281-300.

Gasparini, A. (2014), "The Value of Empathy in Design Thinking", working paper, Innovation in HCI: What can we learn from Design Thinking? (NORDICHI 2014), Helsinki, pp. 8-11.

Gasparini, A.A. (2015), "Perspective and Use of Empathy in Design Thinking", conference Paper, The Eighth International Conference on Advances in Computer-Human Interactions, (ACHI 2015), International Academy, Research, and Industry Association, Lisbon, 22-27 February, pp. 49-54.

Jachnis, A. (2007), Psychologia konsumenta. Psychologiczne i socjologiczne uwarunkowania zachowań konsumenckich, Oficyna Wydawnicza Branta, Bydgoszcz-Warszawa.

Kahneman, D. (2003), "Maps of bounded rationality: A perspective on intuitive judgment and choice", in: Frangsmyr, T. (Ed.), Les Prix Nobel 2002, Almquist \& Wiksell International, Stockholm.

Koskinen, I., Battarbee, K., Mattelmäki, T. (2003), Empathic design: user experience in product design, IT Press, Finland.

Lindstrom, M. (2005), Brand Sense. Build Powerful Brands through Touch, Taste, Smell, Sight, and Sound, Free Press, New York.

Lonsway, B. (2009), Making Leisure Work: Architecture and the Experience Economy, Routledge Press, Oxford.

Muniz, A. Jr, O'Guinn, T. (2001), "Brand Community", Journal of Consumer Research, Vol. 27 No. 3, pp. 412-432.

New, S., Kimbell, L. (2013), "Chimps, Designers, Consultants and Empathy: A “Theory of Mind" for Service Design”, Proceedings of Cambridge Academic Design Management Conference (CADMC 2013), University of Cambridge, Cambridge.

Nussbaum, B. (2011), Design Thinking is a Failed Experiment. So What's Next?, available at: http://www.fastcodesign.com/1663558/design-thinking-is-afailed-experiment-sowhats-next (accessed 30 December 2016).

Osterwalder, A., Pigneur, Y., Bernarda, G., Smith, A., Papadakos, T. (2014), Value Proposition Design. How to create products and services customer want, Wiley, Hoboken.

Pine, J., Gilmore, J. (1999), The Experience Economy, Harvard Business School Press, Boston.

Ries, E. (2011), The Lean Startup: How Today's Entrepreneurs Use Continuous Innovation to Create Radically Successful Businesses, Crown Business, New York.

Schmitt, B.H. (1999), "Experiential Marketing”, Journal of Marketing Management, Vol. 15 No. 1-3.

Schmitt, B.H. (1999), Experiential Marketing. How to get Customers to Sense, Feel, Think, Act, and Relate to your Company and Brands, Free Press, New York.

Spencer, E. (1881), The principles of psychology, Williams and Norgate, London.

Staszewski, W. (2016), „Karkówska śpiewa ze szczęścia”, Newsweek, No. 48.

Stolterman, E. (2008), "The Nature of Design Practice and Implications for Interaction Design Research”, International Journal of Design, Vol. 2 No. 1, pp. 55-65. 